\title{
Penggunaan Metode Inkuiri Dalam Peningkatan Hasil Belajar Bahasa Inggris Di Kelas VII Madrasah Tsanawiyah Muhammadiyah 17 Paciran
}

\author{
M. Chotibuddin, Idzi'Layyinnati, Bahrus Surus \\ Dosen Sekolah Tinggi Ilmu Tarbiyah Muhammadiyah Paciran, Indonesia \\ Email:boedz2012@gmail.com,idziela@gmail.com,bahrussur@gmail.com
}

\begin{abstract}
The Using Inquiry Methods in Increasing Result of Mathematic Study in five grade of Islamic Junior High School. The purpose of this research were (1) to describe steps of inquiry method in increasing result of mathematic study in five grade of Elementary School, (2) identify constraints and solutions using inquiry methods in increasing result of mathematic study in five grade of state elementary school. This research is classroom action research $(C A R)$ conducted in three cycles, each cycle includes the planning, implementation, observation and reflection. The data were analysis using Miles and Huberman interactive model consist of three components are: data reduction, data display, and conclusion drawing/verification. The results showed that (1) the steps of inquiry method can be run apropriate to the scenario, (2) the using inquiry method can increasing result of mathematic study in five grade of Elementary School. Increasing result of mathematic study from pre-test were 40\%, in the first cycle were $60 \%$, in the second cycle were $73 \%$ and the third cycle increase until $80 \%$.
\end{abstract}

Key words: result of study, mathematic, inquiry method 
Pembelajaran Bahasa Inggris membekali siswa dengan kemampuan berpikir kritis dan kreatif, serta bekerjasama. Kompetensi tersebut diberikan agar peserta didik dapat memiliki kemampuan memperoleh, mengelola, dan memanfaatkan informasi untuk memecahkan permasalahan yang dihadapinya. Keberhasilan pembelajaran Bahasa Inggris tersebut tergantung pada siswa dalam proses belajar mengajar, sedangkan keberhasilan siswa tidak hanya tergantung pada sarana dan prasarana pendidikan, serta kurikulumnya. Akan tetapi, guru dalam proses pembelajaran juga dapat mempengaruhi peningkatan hasil belajar Bahasa Inggris siswa, salah satunya dengan penggunaan metode pembelajaran oleh guru sesuai Berdasarkan hasil pengamatan dalam proses belajar mengajar dikelas, keadaan sekolah, dan melalui peninjauan bidang akademik dan non akademik, diperoleh hasil bahwa keadaan MTs Muhammadiyah 17 Paciran khususnya siswa kelas VII tahun ajaran 2016/2017 dalam pelajaran Bahasa Inggris belum menunjukkan hasil belajar sesuai dengan KKM yang ditetapkan. Ditinjau dari keadaan fisik sekolah, yaitu ruang kelas VII sudah baik dan sesuai sebagai tempat berlangsungnya proses belajar mengajar. Pengamatan pada proses pembelajaran oleh peneliti dapat disimpulkan bahwa pelaksana-an proses belajar mengajar belum membuat siswa aktif belajar, sehingga kemampuan siswa belum tergali dengan maksimal. Penggunaan metode pembelajaran dalam pembelajaran Bahasa Inggris belum sesuai dan membuat siswa terlihat tidak antusias untuk belajar. Guru masih terfokus untuk menjelas-kan materi dan siswa hanya melakukan perintah mengerjakan soal tanpa penanaman konsep pembelajaran yang kuat.

Untuk memperoleh hasil belajar yang optimal, tidak hanya memerlukan suatu latihan yang terus menerus, tetapi terlebih dahulu siswa harus mengetahui inti dari materi yang dipelajarinya. Berdasarkan kon-sep yang mereka temukan sendiri di dalam proses pembelajaran, siswa akan lebih bersemangat, dan aktif belajar serta berusaha mencari penyelesaian masalah yang diberikan oleh gurunya dengan menggunakan ke-mampuannya sendiri. Adanya semangat atau motivasi siswa dalam belajar dan konsep yang tertanam dengan baik, diharapkan siswa mampu menyelesaikan setiap tugas yang diberikan dengan prosedur yang benar, sehingga hasil belajar yang diperoleh menjadi lebih baik dari semula.

Oleh karena itu, diperlukan suatu solusi untuk mengatasi hambatanhambatan yang terjadi. Salah satunya dengan pengguna-an metode inkuiri dalam pembelajaran Bahasa Inggris. Metode inkuiri adalah cara penyajian pelajaran yang memberikan kesempatan kepada peserta didik untuk mencari dan menemukan informasi dengan atau tanpa bantuan guru.

Pembelajaran berpusat pada siswa, sehingga siswa diharapkan lebih aktif, antusias, dan berani dalam mencari pe-nyelesaian permasalahan yang dihadapinya, serta memungkinkan siswa menemukan sendiri informasiinformasi yang diperlukan untuk 
mencapai tujuan belajarnya.

Berdasarkan uraian di atas, rumusan masalah yang muncul yaitu 1) bagaimanakah penggunaan metode Inkuiri dalam pe-ningkatan hasil belajar Bahasa Inggris siswa kelas VII MTs Muhammadiyah 17 Paciran tahun ajaran 2016/2017?, 2) apakah penggunaan metode inkuiri dapat meningkatkan hasil belajar Bahasa Inggris siswa kelas VII MTs Muhammadiyah 17 Paciran tahun ajaran 2016/2017?, 3) apakah kendala dan solusinya pada penggunaan metode inkuiri dalam peningkatan hasil belajar Bahasa Inggris siswa kelas VII MTs Muhammadiyah 17 Paciran tahun ajaran 2016/2017?.

Tujuan penelitian ini yaitu 1) men-diskripsikan langkah penggunaan metode inkuiri, 2) mengetahui peningkatan hasil belajar Bahasa Inggris, dan 3) mengetahui kendala, serta solusinya pada penggunaan metode inkuiri dalam peningkatan hasil belajar Bahasa Inggris kelas VII MTs Muhammadiyah 17 Paciran tahun ajaran 2016/2017.

\section{METODE PENELITIAN}

Penelitian dilaksanakan di kelas VII MTs Muhammadiyah 17 Paciran Lamongan. Jumlah subjek peneliti-an 15 siswa yang terdiri atas 8 siswa laki-laki dan 7 siswa perempuan. Waktu penelitian dilaksanakan mulai bulan Maret sampai dengan bulan juni 2017 semester dua tahun ajaran 2016/2017.

Adapun alat pengumpulan data dalam penelitian ini dibagi menjadi dua, yaitu tes dan non tes.
Tes berupa lembar soal evaluasi hasil belajar Bahasa Inggris, dan non tes terdiri dari observasi dan wawancara. Dalam pelaksanaan tindakan, peneliti diamati oleh tiga observer (pengamat) yang bertugas mengamati dan memberikan masukan bagi jalannya penelitian. Data yang diperoleh dalam penelitian ini dibagi menjadi dua yaitu data pra tindakan dan data tindakan yang berupa hasil penelitian. Data hasil penelitian-nya yaitu hasil observasi terhadap langkah penggunaan metode inkuiri dalam pem- belajaran Bahasa Inggris, respon siswa terhadap pembelajaran yang berlangsung, dan hasil tes tertulis.

Analisis data dilakukan melalui analisis kualitatif mengacu pada pendapat Miles dan Hiberman (1984), meliputi tiga alur kegiatan yaitu reduksi data, penyajian data, dan penarikan kesimpulan, yang dilakukan selama dan setelah pengumpulan data selesai (Sugiyono, 2008: 246-253). Untuk menguji dan menjaga keabsahan data, digunakan metode triangulasi data yang melibatkan peneliti, guru kelas VII, teman sejawat, dan guru kelas VIII.

Prosedur penelitian ini menggunakan metode penelitian tindakan kelas (class action research). Langkah atau prosedur penelitian tindakan kelas tersebut, yaitu perencanaan tindakan, pelaksanaan tindakan, pengamatan, dan refleksi. Pada tahap perencanaan, peneliti membuat rencana tindakan atau skenario pembelajaran, mengumpulkan materi dan membuat media pembelajaran, membuat lembar penilaian, dan observasi. Dalam tahap pelaksanaan menggunakan model Kemmis dan Taggart yang meliputi empat tahap, yaitu perencanaan, pelaksanaan tindakan, observasi, dan refleksi (Wiriaatmadja, 2008). Pada 
pelaksanaannya, tahapan ini selalu ber-hubungan dan berkelanjutan dalam prosesnya, serta mengalami perbaikan-perbaikan sampai memenuhi hasil atau tujuan yang diharapkan.

\section{HASIL DAN \\ PEMBAHASAN}

$\begin{array}{cr}\text { Peningkatan hasil belajar } \\ \text { Bahasa } & \text { Inggris } \\ \text { dengan }\end{array}$ menggunakan metode inkuiri dalam pembelajarannya pada siswa kelas VII MTs Muhammadiyah 17 Paciran dilaksanakan dengan tiga siklus. Setiap siklusnya terdiri atas tiga pertemuan, dengan alokasi waktu 2x35 menit setiap pertemuan. Hasil tindakan selama tiga siklus dapat ditinjau dari langkah penggunaan metode inkuri yang sesuai dengan skenario dan hasil belajar yang diperoleh oleh siswa selama pelaksanaan tindakan. Berdasarkan hasil penelitian dari siklus I sampai siklus III dapat dikatakan bahwa langkah-langkah peng-gunaan metode inkuiri dalam pembelajaran Bahasa Inggris sudah sesuai dengan skenario a-tau perencanaan. Hasil observasi terhadap langkah penggunaan metode inkuiri dalam pembelajaran oleh guru pada siklus I sampai siklus III dapat dilihat pada tabel berikut:

Tabel 1. Hasil Observasi Guru pada Siklus I,

II dan III

\begin{tabular}{|l|l|c|}
\hline \multicolumn{3}{|l|}{ Langkah Pemb. Inkuiri } \\
\hline Si. I & Si. II & Si. III \\
\hline 3.19 & 3.45 & 3.72 \\
\hline
\end{tabular}

Berdasarkan tabel 1 dapat disimpulkan bahwa skor rata-rata terhadap langkah penggunaan metode inkuiri oleh guru pada siklus I mencapai 3.19 , sedangkan pada siklus II mencapai 3.45, dan pada siklus III mencapai 3.45. Skor rata-rata langkah penggunaan metode inkuri oleh guru men-capai 3.45 dan kategori baik. Adapun hasil observasi terhadap langkah penggunaan metode inkuiri dalam pembelajaran Bahasa Inggris oleh siswa pada siklus I sampai siklus III dapat dilihat pada tabel berikut:

Tabel 2. Hasil Observasi Siswa pada Siklus I, II dan III

\begin{tabular}{|c|c|c|c|c|}
\hline \multicolumn{3}{|c|}{ Langkah Pemb. Inkuiri } & \multirow{2}{*}{$\begin{array}{c}\text { Rata- } \\
\text { rata }\end{array}$} & \multirow{2}{*}{$\begin{array}{l}\text { Kate- } \\
\text { gori }\end{array}$} \\
\hline Si. I & Si. II & Si. III & & \\
\hline 3.33 & 3.47 & 3.68 & 3.49 & Baik \\
\hline
\end{tabular}

bahwa skor rata-rata terhadap langkah penggunaan metode inkuiri oleh siswa pada siklus I mencapai 3.33, sedangkan pada siklus II mencapai 3.47 , dan pada siklus III mencapai 3.68. Skor rata-rata langkah penggunaan metode inkuri oleh guru mencapai 3.49 dan kategori baik.

Berdasarkan kedua tabel diatas dapat disimpulkan bahwa guru dan siswa melaksanakan langkah penggunaan metode inkuiri dalam pembelajaran Bahasa Inggris dengan baik dan sesuai skenario atau rencana. Selama pelaksanaan tindakan, langkah penggunaan metode inkuiri mengalami perbaikan. Perbaikan tersebut disesuaikan dengan materi pelajaran yang sedang dibahas. Perbaikan atau perubahan yang peneliti lakukan dalam hal perwujudannya dalam pembelajaran, sehingga langkah pokoknya tidak mengalami perubahan dan sesuai dengan teori yang mendasari penggunaan metode inkuiri.

Langkah pembelajaran Bahasa Inggris dengan menggunakan metode Inkuiri mencakup kegiatan guru dan 
siswa. Fokus observasi siswa yaitu pada respon yang diberikan siswa selama pembelajaran berlangsung. Kegiatan guru dalam penggunaan langkah metode inkuiri pada pembelajaran Bahasa Inggris meliputi: menciptakan kerjasama dengan siswa dalam merumuskan masalah, memberikan kesempatan siswa untuk mem-buat hipotesis pembelajaran (masalah), membimbing siswa dalam mencari atau me-ngumpulkan informasi yang relevan, mem-bentuk dan membimbing siswa dalam kelompok kerja atau diskusi untuk mengolah data (informasi), memberikan kesempatan dan rangsangan agar siswa dapat membuktikan jawaban awal berdasarkan hasil diskusinya, serta bersama-sama menyimpulkan hasil diskusi dan pembelajaran. Selanjutnya, kegiatan atau respon siswa dalam pembelajaran Bahasa Inggris dengan metode inkuri meliputi: fokus perhatian siswa terhadap materi yang disampaikan, keaktifan siswa dalam pembelajaran, antusiasme siswa mengikuti pem-belajaran, keaktifan siswa dalam kegiatan diskusi, kerjasama siswa dalam kegiatan diskusi, dan kemampuan siswa dalam ke-lompoknya untuk menyelesaikan tugas atau LKS. Hal tersebut sesuai dengan pendapat Supriyadi mengemukakan bahwa penggunaan metode inkuiri dalam pembelajaran dimulai dengan pemberian stimulus atau rangsangan kepada siswa, memberikan siswa kesempatan untuk merumuskan hipotesis berdasarkan rumusan masalahnya, pengumpulan data, pengolahan data dalam diskusi pembelajaran, membuktikan kebenaran hipotesis, dan menarik sebuah kesimpulan pembelajaran (2009).

Oleh karena itu, dengan adanya proses pembelajaran tentunya terdapat hasil belajar yang dicapai oleh siswa. Hasil belajarnya berupa nilai hasil menjawab pertanyaan yang diberikan guru dalam soal Bahasa Inggris dari pra-tindakan, siklus I sampai siklus III dengan harapan hasilnya mengalami peningkatan. Adapun perolehan hasil belajar Bahasa Inggris

siswa pada pre-test, siklus I sampai III, sebagai berikut:

Tabel 3. Perolehan Hasil Belajar Bahasa Inggris

\begin{tabular}{lcccc}
\hline \multirow{2}{*}{ Tindak- } & \multicolumn{3}{c}{ Hasil Belajar Bahasa Inggris } \\
\cline { 2 - 5 } & \multicolumn{2}{c}{ Tuntas } & \multicolumn{2}{c}{ Belum Tuntas } \\
\cline { 2 - 5 } & Frek. & $\%$ & Frek. & $\%$ \\
\hline Pretest & 6 & 40 & 9 & 60 \\
Sik. I & 9 & 60 & 6 & 40 \\
Sik. II & 11 & 73.3 & 4 & 26.7 \\
Sik. III & 12 & 80 & 3 & 20 \\
\hline
\end{tabular}

Berdasarkan tabel 3 menunjukkan bahwa hasil belajar Bahasa Inggris siswa kelas V semakin meningkat. Hal tersebut ditunjukkan pada kegiatan pre-test atau tes awal, siswa yang mencapai nilai hasil belajar $\geq$ KKM baru mencapai $40 \%$ atau sebanyak 6 siswa. Pada siklus I persentase pencapaian hasil belajar Bahasa Inggris siswa mengalami peningkatan $20 \%$ menjadi $60 \%$ atau sebanyak 9 siswa. Selanjutnya, pada siklus II persentase siswa yang mencapai nilai hasil belajar $\geq \mathrm{KKM}$ $73.3 \%$ atau sebanyak 11 siswa. Sedangkan disiklus III persentase siswa yang mencapai ketuntasan hasil belajar Bahasa Inggris yaitu $80 \%$ atau 
sebanyak 12 siswa. Adapun siswa yang belum tuntas atau nilai hasil belajarnya $<$ KKM yaitu $20 \%$ atau sebanyak 3 siswa.

Penggunaan metode
inkuiri dalam pembelajaran
Bahasa Inggris yang sesuai
dengan skenario dikelas VII
MTs Muhammadiyah 17 Paciran
tahun ajaran 2016/2017 menjadi
salah satu cara atau langkah agar
dapat meningkatkan hasil belajar
siswa. Digunakannya metode
inkuiri dalam pem-belajaran
Bahasa Inggris memberikan ke-
sempatan dan kemudahan
kepada siswa untuk mencari dan
menemukan konsep atau inti
materi, serta menyelesaikan soal.
Siswa menjadi lebih aktif dalam
mengembangkan kiswa
kemampuannya karena siswa
yang mem-bangun pengetahuan
dan keterampilannya sendiri
melalui aktivitas belajar
mencari, menemukan, dan
menyimpulkan pembelajar-an
yang telah disepakati.

Dengan penguasaan konsep atau materi yang baik dan kemampuan siswa untuk menggunakan keterampilannya dalam berlatih menyelesaikan soal secara baik, maka hasil belajarnya akan mengalami peningkatan. Sebelum digunakannya langkah penggunaan metode inkuiri dalam pembelajaran Bahasa Inggris, siswa langsung diarah-kan pada latihan menyelesaikan soal. Namun, dengan langkah metode inkuiri dalam pembelajaran Bahasa Inggris, siswa dibekali konsep dan pengalaman belajar sehingga akan lebih mudah dalam memecahkan atau menyelesaikan soal evaluasi belajar. Hal tersebut sejalan dengan pendapat Buchari Alma yang menyatakan bahwa kelebihan metode inkuiri adalah mampu mendorong siswa untuk bertindak aktif mencari jawaban dari permasalah-permasalahan yang dihadapi-nya dengan menarik kesimpulan sendiri dengan berpikir ilmiah, logis, dan sistematis. Dengan demikian penggunaan metode inkuiri dapat meningkatkan hasil belajar siswa karena siswa mendapatkan keterampilan menyelesai-kan soal atau masalah berdasarkan langkah-langkah yang dibuatnya sendiri (2010).

Adapun kendala atau hambatan yang muncul pada penggunaan metode inkuiri dalam peningkatan hasil belajar Bahasa Inggris siswa kelas VII MTs Muhammadiyah 17 Paciran tahun ajaran 2016/2017 antara lain: kebiasaan belajar beberapa siswa yang masih berpusat pada guru (konvensional), waktu yang digunakan dalam pembelajaran mate-matika seringkali belum efektif, sumber belajar siswa sebagian besar masih berpusat pada buku yang disediakan, dan ada siswa yang memiliki 
keterlambatan belajar, sehingga belum mampu belajar sendiri dalam aktifitas penggunaan langkah metode inkuiri dalam pembelajaran Bahasa Inggris. Hal tersebut sejalan dengan pendapat Sumantri dan Permana yang menyatakan bahwa kelemahan metode inkuiri antara lain: memerlukan fasilitas yang memadai, sulitnya mengubah cara belajar siswa dari konvensional menjadi aktif, kebebasan yang diberikan guru terkadang tidak dimanfaatkan dengan secara optimal oleh siswa, sehingga waktu yang diperlukan semakin banyak atau tidak efektif (2001: 143-144). Solusi dari permasalahan tersebut yang dilakukan oleh peneliti antara lain: memberikan kuis atau pertanyaan terfokus, sehingga siswa mempunyai motivasi dan batasan untuk mencari jawaban, pembagian kelompok belajar oleh peneliti dilakukan sebelum pelajaran dimulai dan diusahakan berbeda pada setiap pertemuannya dengan tujuan agar tercipta kerjasama yang baik antar siswa, serta penggunaan media pembelajaran dan perpustakaan secara opti-mal sebagai sumber belajar selain buku. Untuk siswa yang mengalami keterlambatan belajar akan diserahkan penanganannya kepada guru kelas dengan pertimbangan lebih mengetahui karakteristik peserta didiknya.

Selanjutnya, peneliti menyimpulkan bahwa keberhasilan penelitian ini juga ditentukan oleh strategi dalam mempraktik-kan langkah penggunaan metode inkuiri dalam pembelajaran Bahasa Inggris selama pelaksanaan tindakan. Selain itu, pengelolaan kelas perlu mendapatkan perhatian agar semua peserta didik terkontrol dengan baik saat pembelajaran berlangsung. Penyediaan sarana pendidikan, buku dan media pem-belajaran yang relevan dengan materi serta sesuai dengan jumlah siswa kelas V. Semakin terkotrolnya siswa dalam pembelajaran. Kemudian, keaktifan siswa dalam kegiatan tanyajawab, penugasan, dan diskusi selama pelaksanaan tindakan terutama pada siklus II dan III dapat meningkatkan pembelajaran Bahasa Inggris dari guru maupun siswa. Hal tersebut pada akhirnya memberikan pengaruh positif terhadap peningkatan hasil belajar Bahasa Inggris siswa kelas V. Hal tersebut sejalan dengan pendapat yang dikemukakan oleh Akhmad Sudrajat bahwa pada langkah penggunaan metode inkuri, guru hendaknya memberikan ruang kepada siswa untuk belajar aktif sesuai dengan gaya belajar mereka, dan peran guru fasilitator serta pembimbing (kontrol) pembelajaran kepada siswa (2011: 135-136).

\section{SIMPULAN DAN SARAN}

Berdasarkan hasil penelitian tentang penggunaan metode inkuiri dalam pe-ningkatan hasil belajar siswa kelas VII MTs Muhammadiyah 17 Paciran tahun ajaran 2016/2017 dapat disimpulkan bahwa penggunaan metode inkuiri dalam pembelajaran Bahasa Inggris sudah sesuai skenario dan dapat mening-katkan hasil belajar Bahasa Inggris siswa kelas VII MTs Muhammadiyah 17 Paciran tahun ajaran 2016/2017.

Selanjutnya, dari hasil penelitian di- 
atas, peneliti memberikan saran kepada sekolah, khususnya guru kelas V. Pada pem belajaran Bahasa Inggris pokok bahasan pecahan dapat menggunakan metode pembelajaran inkuiri karena dapat merangsang siswa untuk aktif dan antusias dalam belajar, sehingga hasil belajar siswa meningkat.

\section{DAFTAR PUSTAKA}

Alma, B. 2010. Guru Profesional Menguasai

Bandung: Alfabeta.

Sudrajat, A. 2011.

Kurikulum Dan

Pembelajaran Dalam

Paradigma

Baru. Yogyakarta:

Paramitra

Sugiyono. 2009. Metode Penelitian

Kuantitatif Kualitatif

dan $R \& D$.

Bandung: Alfabeta.

Sumantri, M dan Permana, J.

2001. Strategi Belajar Mengajar.

Bandung: CV. Maulana.

Supriyadi. 2011. Strategi Belajar

Mengajar.

Surabaya: Cakrawala Ilmu.

Wiriaatmadja, R. 2008. Metode

Penelitian

Tindakan Kelas.

Bandung: Rosdakarya. 


